Int. J. of Electronics Engineering and Applications, Volume 8, Issue II, July-Dec. 2020

\title{
HEURISTIC-BASED USABILITY EVALUATION ON MOBILE APPLICATION FOR READING DISABILITY
}

\author{
Onintra Poobrasert, Sirilak Luxsameevanich, Sarinya Chompoobutr, Natcha \\ Satsutthi, Sakda Phaykrew and Paweena Meekanon
}

\begin{abstract}
Most of the learning disabilities (LD)children have writing and reading disorders as a majorproblem. The calculating disorder is the second problem. Therefore, it should focus on reading and writing teaching to help these LD children because theyare important skills in learning. If the children cannot read or write, it will obstruct their learning. Nowadays, everybody can learn by himself because of technological advances and modernity. We can access all knowledge via computer, smartphone or any technological devices. Hence, if the children who cannot read or write, they cannot access the information, news or any knowledge as the others do. However, if the LD children were appropriately helped, they will be able to learn faster. Therefore, in this study we intend to develop the assistive technology for students with learning disabilities; focusing on their reading and spelling. The heuristic evaluation results showed that the application is suitable for the students with learning disabilities and able to help them in their reading vocabularies. Finally, the use of new technology such as QR code technique will also gain attentionfrom smallstudents.
\end{abstract}

Keywords-Assistive Technology, Leaming Disabilities, Dyslexia, Reading, QR Code.

Reference to this paper should be made as follows:

Onintra Poobrasert, Sirilak Luxsameevanich, Sarinya Chompoobutr, Natcha Satsutthi, Sakda Phaykrewand Paweena Meekanon. "HEURISTIC-BASED USABILITY EVALUATIONON MOBILE APPLICATION FOR READING DISABILITY “, International Journal of Electronics Engineering and Applications, 8, Issue II, July-Dec. 2020, PP-11-21.

\section{Biographicalnotes:}

Dr. Onintra Poobrasert: Senior Researcher, Assistive Technology and Medical Devices Research Center, National Science and Technology Development Agency, Pathumthani, Thailand

Sirilak Luxsameevanich: Senior Technical Officer, Assistive Technology and Medical Devices Research Center, National Science and Technology Development Agency, Pathumthani, Thailand.

Sarinya Chompoobutr: Senior Research Assistant, Assistive Technology and Medical Devices Research Center, National Science and Technology Development Agency, Pathumthani, Thailand

Natcha Satsutthi: Research Assistant, Assistive Technology and Medical Devices Research Center, National Science and Technology Development Agency, Pathumthani, Thailand

Sakda Phaykrew: NSTDA Co-Researcher, Assistive Technology and Medical Devices Research Center, National Science and Technology Development Agency, Pathumthani, Thailand

Paweena Meekanon:Ph.D. candidate, Trudy Busch Valentine School of Nursing, Saint Louis University, MO, USA. 


\section{[1] INTRODUCTION}

The research report of the Special Education Bureau on the Development of Educational Disability Screening in Dyslexia type, found that the Dyslexia is the most existing disability with 29.25 percent [1]. In addition, comparing with the other students, the LD students have generally a low-average school record [2]. Therefore, it is indispensable for all organizations related to LD children to take action and to develop the LD children's reading, writing and calculating skills [3].

According to the mentioned information, the research team at Assistive Technology and Medical Devices Research Center (A-MED) gives precedence to help these children. So, the research team develops an application for reading the Thai vocabulary. This application will help improve LD children in their reading skills. The application works by scanning its QR code. The QR code is a rapid active symbol that stores information [4]. The code was used mostly for commercial purposes or advertisements in order to add detailed information or URL of website. When we scan it by our smartphone or tablet camera, we can access directly to the website without wasting our time [5]. The researchers apply this QR code technology to develop the application for children with Learning Disabilities [6].

\section{[2] METHODOLOGY}

The application was designed to help the children with Learning disabilities to read correctly. When they can read, they can further improve their writing potential. The application functions are as follows:

- It is an application that help the children with learning disabilities to read correctly.

- It is an application that can be use with the special QR code that was created particularly for this application.

- It is an application that can be scanned via QR code. Then, the spelling of Thai words and their pronunciation will appear automatically. [Figure-1]

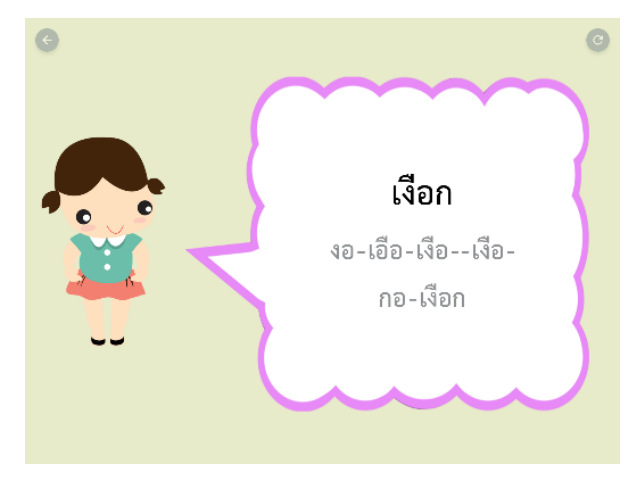

Figure: 1. The Spelling of Thai Words and their Pronunciation.

- It is an application which the users can review the preceding words when they scan the QR code for the first time. The users do not need to rescan the QR code. [Figure-2] 


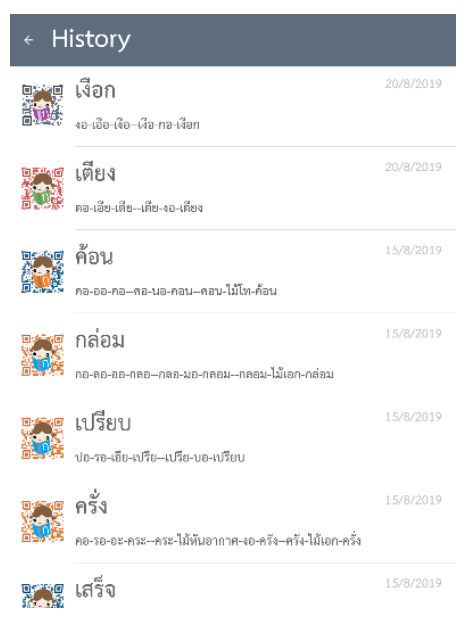

Figure: 2. The History.

- This application works on any smartphone and tablets with Android operation version 5.0 and above and have at least 5.5 inches of display.

Concerning the system design, the research team created the QR code that provides the detailed spelling function. For example, the application will show the word kin (to eat) in Kor-iki-ki-nor-kin form with its pronunciation.

\section{[3] ANALYSES OF THE HEURISTIC EVALUATION}

The efficiency and appropriateness assessment of the application applies the Heuristic Evaluation which is an evaluation and inspection of application design [7, 8]. The process will discover primary problems that should be amended before using with the LD children. This spelling application was already passed the efficiency assessment by the 10 assessors. The details are as follows:

\section{[3.1] THE EVALUATION RESULT RELATING TO PERSONAL INFORMATION OF THE PARTICIPANTS}

\section{Table 1: Total Participants and Percent Classified by Genders}

\begin{tabular}{c|c|c|} 
Gender & Participants (person) & percent \\
\hline Male & 5 & 50 \\
\hline Female & 5 & 50 \\
\hline Total & $\mathbf{1 0}$ & $\mathbf{1 0 0}$ \\
\hline
\end{tabular}

According to Table 1 Total participants and percent classified by genders, it found that there is the same amount of male and female participants. There were both 5 persons for each. This represents 50 percent of male participants and 50 percent of female participants. 
Onintra Poobrasert, Sirilak Luxsameevanich, Sarinya Chompoobutr, Natcha Satsutthi, Sakda Phaykrew and Paweena Meekanon

Table 2: Total Participants and Percent Classified by Age

\begin{tabular}{c|c|c|}
\multicolumn{1}{c|}{ Age } & Participants (person) & percent \\
\hline $20-24$ & 4 & 40 \\
\hline $25-29$ & 3 & 30 \\
\hline $30-34$ & 1 & 10 \\
\hline $35-39$ & 2 & 20 \\
\hline $40-44$ & - & - \\
\hline 45 above & - & - \\
\hline Total & $\mathbf{1 0}$ & $\mathbf{1 0 0}$ \\
\hline
\end{tabular}

According to Table 2 Total participants and percent classified by age, it found that most of the participants were between 20 and 24 years old. There are 4 participants with the age between 20 and 24 years, which represents 40 percent of all participants. There are 3 participants with the age between 25 and 29 years, which represents 30 percent.

Table 3: Total Participants and Percent Classified by Expertise

\begin{tabular}{c|c|c|}
\hline Expertise & Participants (person) & percent \\
\hline Facility Technology & 1 & 10 \\
\hline Designing & 2 & 20 \\
\hline Disabled person /IT & 1 & 10 \\
\hline Programming & 4 & 40 \\
\hline Microsoft Office & 1 & 10 \\
\hline No comment & 1 & 10 \\
\hline Total & $\mathbf{1 0}$ & $\mathbf{1 0 0}$ \\
\hline
\end{tabular}

According to Table 3 Total participants and percent classified by expertise, it found that most of the participants were experts in programming. There are 4 participants specializing in programming, which represents 40 percent of the participants. There were 2 experts in designing, which represent 20 percent.

Table 4: Total Participants and Percent Classified by Experience Related to LD Child

\begin{tabular}{c|c|c|} 
Experience (Year) & Participants (person) & percent \\
\hline Less than 1 year & 2 & 20 \\
\hline 1.5 years & 7 & 70 \\
\hline More than 5 Years & 1 & 10 \\
\hline Total & $\mathbf{1 0}$ & $\mathbf{1 0 0}$ \\
\hline
\end{tabular}

According to Table 4 Total participants and percent classified by experience related to LD child, it found that most of the participants have 1-5 years of experience with an LD child. There were 7 participants $1-5$ years of experience, which represents 70 percent of participants. There were 2 people having inferior to 1 year of experience, which represents 20 percent of the participants. 


\section{[3.2] INFORMATION RELATING TO SATISFACTION TOWARDS THE SPELLING APPLICATION}

Table 5: Total Participants and Percent Classified by the Practical Use of the Applications Design

\begin{tabular}{c|c|c|}
$\begin{array}{c}\text { Application was designed } \\
\text { for a practical use }\end{array}$ & Participants person) & Percent \\
\hline Highest & 8 & 20 \\
\hline High & 2 & - \\
\hline Average & - & - \\
\hline Low & - & - \\
\hline Lowest & - & - \\
\hline No Comment & - & $\mathbf{1 0 0}$ \\
\hline Total & $\mathbf{1 0}$ & \\
\hline
\end{tabular}

According to Table 5 Total participants and percent classified by the practical use of the application's design, it found that there were 8 participants, representing 80 percent, satisfied with the design at the highest level. There were 2 participants, representing 20 percent, satisfied with the design at a high level.

Table 6: Total Participants and Percent Classified by Appropriateness of the Type Style on the Display

\begin{tabular}{c|c|c|}
$\begin{array}{c}\text { Appropriateness of Type Style } \\
\text { on the Display }\end{array}$ & Participants (person) & Percent \\
\hline Highest & 6 & 60 \\
\hline High & 4 & 40 \\
\hline Average & - & - \\
\hline Low & - & - \\
\hline Lowest & - & - \\
\hline No Comment & - & $\mathbf{1 0 0}$ \\
\hline Total & $\mathbf{1 0}$ & - \\
\hline
\end{tabular}

According to Table 6 Total participants and percent classified by appropriateness of the Type Style on the display, it found that there were 6 participants, representing 60 percent, satisfied with the type style at the highest level. There were 4 participants, representing 40 percent, satisfied with the type style at a high level. 
Onintra Poobrasert, Sirilak Luxsameevanich, Sarinya Chompoobutr, Natcha Satsutthi, Sakda Phaykrew and Paweena Meekanon

Table 7: Total Participants and Percent Classified by Appropriateness of the Type Size on the Display

Appropriateness of Type Size

Participants (person)

Percent

on the Display

\begin{tabular}{c|c|c|}
\hline Highest & 5 & 50 \\
\hline High & 5 & 50 \\
\hline Average & - & - \\
\hline Low & - & - \\
\hline Lowest & - & - \\
\hline No Comment & - & - \\
\hline Total & $\mathbf{1 0}$ & $\mathbf{1 0 0}$ \\
\hline
\end{tabular}

According to Table 7 Total participants and percent classified by appropriateness of the Type Size on the display, it found that there were 5 participants, representing 50 percent, satisfied with the type size on the display at the highest level. There were also 5 participants, representing 50 percent, satisfied with the type size at a high level.

Table 8: Total Participants and Percent Classified by Appropriateness of Type color

\begin{tabular}{c|c|c|} 
Appropriateness of Type color & Participants (person) & Percent \\
\hline Highest & 6 & 60 \\
\hline High & 4 & 40 \\
\hline Average & - & - \\
\hline Low & - & - \\
\hline Lowest & - & - \\
\hline No Comment & - & - \\
\hline Total & $\mathbf{1 0}$ & $\mathbf{1 0 0}$ \\
\hline
\end{tabular}

According to Table 8 Total participants and percent classified by appropriateness of Type color, it found that there were 6 participants, representing 60 percent, satisfied with the type color at the highest level. There were 4 participants, representing 40 percent, satisfied with the type color at a high level.

Table 9: Total Participants and Percent Classified by Appropriateness of Active Sound Function

Appropriateness of Active

Participants (person)

Percent

Sound Function

\begin{tabular}{c|c|c|}
\hline Highest & 4 & 40 \\
\hline High & 6 & 60 \\
\hline Average & - & - \\
\hline Low & - & - \\
\hline Lowest & - & - \\
\hline No Comment & - & - \\
\hline Total & $\mathbf{1 0}$ & $\mathbf{1 0 0}$ \\
\hline
\end{tabular}


According to Table 9 Total participants and percent classified by appropriateness of the active sound function, it found that there were 6 participants, satisfied with the active sound function at the highest level and 4 participants, satisfied at a high level.

Table 10: Total Participants and Percent Classified by the Appropriated Use of Application for Educational Purposes

Appropriated Use of

Participants (person)

Percent

Application for Educational

\begin{tabular}{|c|c|c|}
\hline Purposes & & \\
\hline Highest & 4 & 40 \\
\hline High & 5 & 50 \\
\hline Average & - & - \\
\hline Low & - & - \\
\hline Lowest & - & - \\
\hline No Comment & 1 & 10 \\
\hline Total & 10 & 100 \\
\hline
\end{tabular}

According to Table 10 Total participants and percent classified by the appropriated use of application for educational purposes, it found that there were 5 participants, representing 50 percent, satisfied with use of application for educational purposes at the highest level. There were 4 participants, representing 40 percent, satisfied with the use of application for educational purposes at a high level.

\section{[3.3] THE CORRECTNESS AND POTENTIAL EVALUATION OF THE SPELLING APPLICATION}

Table 11: Total Participants and Percent Classified by the Correctness of Information

\section{Searching}

Correctness of Information

Participants (person)

Percent

Searching

\begin{tabular}{c|c|c|}
\hline Highest & 7 & 70 \\
\hline High & 2 & 20 \\
\hline Average & - & - \\
\hline Low & - & - \\
\hline Lowest & - & - \\
\hline No Comment & 1 & 10 \\
\hline Total & $\mathbf{1 0}$ & $\mathbf{1 0 0}$ \\
\hline
\end{tabular}

According to table 11 Total participants and percent classified by the correctness of information searching, it found that there were 7 participants, representing 70 percent, satisfied with the correctness of information searching at the highest level. There were 2 participants, representing 20 percent, satisfied with the correctness of information searching at a high level. 
Table 12: Total Participants and Percent Classified by Rapidity of Information Processing

Rapidity of Information

Processing

\begin{tabular}{c|c|c|}
\hline Highest & 6 & 60 \\
\hline High & 4 & 40 \\
\hline Average & - & - \\
\hline Low & - & - \\
\hline Lowest & - & - \\
\hline No Comment & - & - \\
\hline Total & $\mathbf{1 0}$ & $\mathbf{1 0 0}$ \\
\hline
\end{tabular}

According to Table 12 Total participants and percent classified by the rapidity of information processing, it found that there were 6 participants, representing 60 percent, satisfied with the rapidity of information processing at the highest level. There were 4 participants, representing 40 percent, satisfied with the rapidity of information processing at a high level.

\section{Table 13: Total Participants and Percent Classified by the Simplicity of Application}

\begin{tabular}{c|c|c|}
\hline Simplicity of $A$ pplication & Participants (person) & percent \\
\hline Highest & 8 & 80 \\
\hline High & 2 & 20 \\
\hline Average & - & - \\
\hline Low & - & - \\
\hline Lowest & - & - \\
\hline No Comment & - & - \\
\hline Total & $\mathbf{1 0}$ & $\mathbf{1 0 0}$ \\
\hline
\end{tabular}

According to Table 13 Total participants and percent classified by the simplicity of application, it found that there were 8 participants, representing 80 percent, satisfied with the simplicity of application at the highest level. There were 2 participants, representing 20 percent, satisfied with the simplicity of application at a high level.

Table 14: Total Participants and Percent Classified by the Information Accuracy

\begin{tabular}{c|c|c|}
\hline Information accuracy & Participants person) & Percent \\
\hline Highest & 7 & 70 \\
\hline High & 3 & 30 \\
\hline Average & - & - \\
\hline Low & - & - \\
\hline Lowest & - & - \\
\hline No Comment & - & - \\
\hline Total & $\mathbf{1 0}$ & $\mathbf{1 0 0}$ \\
\hline
\end{tabular}

According to Table 14 Total participants and percent classified by the information accuracy, it found that there were 7 participants, satisfied with the information accuracy at the highest level and 3 participants, satisfied at a high level. 
Table 15: Total Participants and Percent Classified by the Convenient and Uncomplicated Accessibility of Information

Convenient and

Uncomplicated Accessibility

\begin{tabular}{c|c|c}
\hline Uncomplicated Accessibility & 8 & 80 \\
\hline Highest & 2 & 20 \\
\hline High & - & - \\
\hline Average & - & - \\
\hline Low & - & - \\
\hline Lowest & - & - \\
\hline No Comment & $\mathbf{1 0}$ & $\mathbf{1 0 0}$ \\
\hline Total & &
\end{tabular}

According to Table 15 Total participants and percent classified by the convenient and uncomplicated accessibility of information, it found that there were 8 participants, representing 80 percent, satisfied with the convenient and uncomplicated accessibility of information at the highest level. There were 2 participants, representing 20 percent, satisfied with the convenient and uncomplicated accessibility of information at a high level.

\section{[3.4] EVALUATION OF OVERALL SATISFACTION}

Table 16: Total Participants and Percent Classified by the Overall Satisfaction about this Spelling Application

Overall Satisfaction about the

Participants (person)

Percent

Spelling Application

\begin{tabular}{|c|c|c|}
\hline Highest & 4 & 40 \\
\hline High & 6 & 60 \\
\hline Average & - & - \\
\hline Low & - & - \\
\hline Lowest & - & - \\
\hline No Comment & - & - \\
\hline Total & $\mathbf{1 0}$ & $\mathbf{1 0 0}$ \\
\hline
\end{tabular}

According to Table 16 Total participants and percent classified by the overall satisfaction about this spelling application, it found that there were 6 participants, representing 60 percent, satisfied with the overall satisfaction about this spelling application at the highest level. There were 4 participants, representing 40 percent, satisfied with the overall satisfaction about this spelling application at a high level.

Further result stated that 8 participant, representing 80 percent, thought the application is suitable for the LD children in many perspectives such as the application can be applied to use with a child who start writing a word. The application can also apply to use with other subjects because the children can see and hear a word in the same time. It is suitable for applying to use as supplement in the classroom because the application is interesting and colorful [9]. It 


\section{Onintra Poobrasert, Sirilak Luxsameevanich, Sarinya Chompoobutr, Natcha Satsutthi, Sakda Phaykrew and Paweena Meekanon}

encourages the children to use and practice the spelling. However, there were 2 participants, representing 20 percent, had no comment in this point.

\section{[4] CONCLUSION AND FUTURE SCOPE}

This article presented the development of assistive technology for students with learning disabilities. As shown in the results, the spelling application is suitable for LD students in many perspectives and can be able to apply to use as supplement in the classroom. The application is an excellent tool to motivate small students to learn how to spell vocabularies [10].

The provided analyses for heuristic evaluation in this study are quite good however, there are some improvements that can still be accomplish such as

(1) It should have a picture for each vocabulary in the application. It will make easier for the children to memorize the spelling and picture. This will make the spelling more interesting for the kids.

(2) The Application should be in a vertical line or should use only vertical or horizontal line for the practical use.

(3) There are many ways of spelling. However, the spelling ignorance could cause children confused.

(4) QR Code should be bigger.

(5) The researcher recommends that the QR Code in a card shall be in one corner.

According to the information above, the researchers will take all recommendations, which were passed the heuristic evaluation, to improve the prototype to be more suitable for the students with learning disabilities. 


\section{REFERENCES}

[1] Ministry of Education. (2019).Core Education Curriculum. Retrieved [July 2020] from the World Wide Web:http://academic.obec.go.th/newsdetail.php?id=75.

[2] Dysgraphia. (2014). Retrieved [July 2020] from the World Wide Web: http://educationportal.com/academy/lesson/what-is-dysgraphia-symptoms-treatment-definition.html\#lesson.

[3] Berninger, V.\& Wolf, B. (2009). Teaching Students with Dy slexia and Dysgraphia:Lessons from Teaching and Science. Paperback. Brookes Publishing; $1^{\text {st }}$ edition. ISBN-10: 1557669341.

[4] Chen, N.-S. et al., (2010). Augmenting Paper-Based Reading Activities with Mobile Technology to Enhance Reading Comprehension. WMUTE '10 Proceedings of the 2010 6th IEEE International Conference on Wireless, Mobile, and Ubiquitous Technologies in Education. Kaohsiung, Taiwan, pp. 201-203.

[5] Fox, Alexander. (2019). The Anatomy of a QR Code:How QR Codes Work. Retrieved [May 2020] from the World Wide Web: https:/www.maketecheasier.comhow-qr-codes-work.

[6] Rikala, J., and Kankaanranta, M., (2012). The Use of Quick Response Codes in the Cla ssroom. $11^{\text {th }}$ Conference on Mobile and Contextual Learning. Helsinki, Finland, pp.148-155.

[7] Yeni, S., Cagiltay, K. \& Kara su, N. (2020). Usability investigation of an educational mobile application for individuals with intellectual disabilities. Univ Access Inf Soc 19, 619-632, https:/doi.org/10.1007/s10209-019-00655-0.

[8] William, P., Nicholas, D. (2006). Testing the usability of information technology a pplications with learners with specialeducational needs (SEN). J. Res. Spec. Educ. Needs 6(1), 31_41.

[9] Bromley, K. (2012). Using Smartphones to supplement cla ssroom reading. Retrieved [June 2020] from the World Wide Web: https://oi.org/10.1002/TRTR.01130.

[10] Ciampa, K. (2015). Motivating Grade 1 Children to Read: Exploring the Role of Choice, Curiosity, and Challenge in Mobile Ebooks, Reading Psychology, $10.108002702711 .2015 .1105337,37,5,(665-705)$.

[11]S. Remya and R. Sasikala, "Performance evaluation of optimized and adaptive neuro fuzzy inference system for predictive modeling in agriculture," Computers \& Electrical Engineering, vol. 86, p. 106718, 2020.

[12]Rajesh Kumar Tiwa ri, (2020), "Human age estimation using Machine Learning Techniques” Int. J. of Electronics Engineering and Applications, Vol. 8, No. 1, pp. 01 -09

[13]Jeeva n Kumar and Rajesh Kumar Tiwa ri, (2020), “A novel deep learning framework for forgery detection in images File" Int. J. of Electronics Engineering and Applications, Vol. 8, No. 1, pp. 19-29 